\title{
Electroreduction of Salicylic Acid, Acetylsalicylic Acid and Pharmaceutical Products Containing these Compounds
}

\author{
Edyta Wudarska, Ewa Chrzescijanska, ${ }^{*}$ Elzbieta Kusmierek \\ Institute of General and Ecological Chemistry, Department of Chemistry, \\ Technical University of Lodz, Poland
}

Received 18 July 2014; accepted 18 August 2014

\begin{abstract}
Electroreduction properties of salicylic (SA) and acetylsalicylic (ASA) acids were investigated at platinum electrode using the voltammetry method. Cyclic voltammograms $(\mathrm{CV})$ of the tested compounds were used in determining half-wave potential $\left(\mathrm{E}_{1 / 2}\right)$ - the parameter describing the anti-reductive properties. The content of active substances (SA and ASA) in the selected pharmaceuticals (salicylic alcohol, Bayer aspirin, etopirin and polopirin) was examined with the application of electrochemical and spectrophotometric methods.
\end{abstract}

Keywords: Cyclic voltammograms; Electroreduction; Salicylic acid; Acetylsalicylic acid; Pharmaceutical products.

\section{Introduction}

Salicylates constitute a group of organic compounds, commonly used in the prevention and curing of many diseases. Salicylic intoxication causes symptoms that can be mild up to very severe and even result in a sudden death [1,2]. Salicylic acid (o-hydroxybenzoic acid, SA, Fig. 1A) belongs to this group of compounds. It is used in the pharmaceutical industry in production of drug and cosmetic preparations (ointments, creams and gels) for skin care [3]. SA used in these preparations regulates a skin cell renewal and shows exfoliation activity by loosening of intercellular connections resulting in removal of cornfield epidermal cell layer. Due to its structure and medicinal properties, SA belongs to the group nonsteroidal anti-inflammatory drugs (NSAIDs) [4].

Since SA had been the first time synthesized, researches for new antiinflammatory drugs but with higher therapeutic activity have been carried out.

\footnotetext{
* Corresponding author. E-mail address: ewa.chrzescijanska@p.lodz.pl
} 
Many NSAIDs belonging to various chemical groups, with different antiinflammatory, analgesic and antipyretic activity, were developed [5]. Active substances in NSAIDs include also acetylsalicylic acid (o-acetoxybenzoic acid, aspirin, ASA, Fig. 1B) applied in curing pain and fever decrease [6, 7].

(A)<smiles>O=C(O)c1ccccc1O</smiles>

(B)<smiles>CC(=O)Oc1ccccc1C(=O)O</smiles>

Figure 1. Chemical structure of salicylic (A) and acetylsalicylic (B) acids.

Like other drugs, salicylic acid and acetylsalicylic acid also cause some side effects. The use of SA and ASA can lead to gastrointestinal complications that may pose a direct threat to life (bleeding, stenosis, perforation), especially for children and elderly patients [8]. Thus, it is necessary to develop methods of their determination in human body fluids.

Last years, applications of electrochemical methods in determination and studies of drugs attract a lot of attention because of their accuracy and simplicity [9-17]. Electrochemical measurements enable determination of various physicochemical parameters of tested compounds, e.g. redox potential, half-wave potential, reduction currents, which can be used in calculation of kinetic parameters of electrode reactions like number of exchanged electrons, transfer coefficients, rate constants of electrode reactions. These parameters are important in estimation of anti-reductive properties of drugs as well as in understanding of their reduction mechanisms [18-23].

The aim of the investigations described in this paper was determining SA and ASA electrochemical behaviour in the process of their electroreduction at platinum electrode. According to our best knowledge, electroreduction of ASA is poorly described in literature in contrary to its electrooxidation. Determination of active substances concentrations in selected pharmaceuticals was carried out using the cyclic voltammetry method and UV-VIS spectrophotometry. The tested pharmaceuticals were as follows: salicylic alcohol, Bayer aspirin, etopirin and polopirin.

\section{Experimental \\ Reagents}

The pure salicylic (SA) and acetylsalicylic (ASA) acids were purchased in Sigma-Aldrich (Germany) and used as received. Pharmaceutical products (salicylic alcohol, Bayer aspirin, etopirin and polopirin) containing tested compounds were purchased in pharmacies in Lodz. The concentration of SA and ASA solutions varied in the range from $0.2 \times 10^{-3}$ to $5 \times 10^{-3} \mathrm{~mol} \mathrm{~L}^{-1}$. The aqueous solutions of tested compounds were prepared by their dissolution in the supporting electrolyte $\left(0.1 \mathrm{~mol} \mathrm{~L}^{-1} \mathrm{NaClO}_{4}\right.$, Fluka, France). 


\section{Measurement methods}

Voltammetric analysis

Electroanalytical measurements of SA, ASA and the pharmaceuticals were carried out in an Autolab PGSTA30 Electrochemical Analyzer (Eco Chemie, Netherlands). A three-electrode electrochemical cell employed in measurements consisted of a reference electrode, an auxiliary electrode (platinum wire) and a working electrode - platinum with geometric surface area of $0.5 \mathrm{~cm}^{2}$. A potential of the working electrode was measured vs. saturated calomel electrode (SCE). Measurements were carried out using a method of cyclic voltammetry (CV). CV curves were recorded in the potential from 0 to 1.25 with various scan rates $(0.01$ to $\left.0.1 \mathrm{~V} \mathrm{~s}^{-1}\right)$. The volume of the solutions used in the measurements was $20 \mathrm{~mL}$. Prior to the measurements, the solution was purged with argon in order to remove dissolved oxygen. During measurements, argon blanket was kept over solutions. All experiments were carried out at room temperature.

Spectrophotometric analysis

UV-VIS spectra of the tested compounds were recorded in the wavelength range from 180 to $800 \mathrm{~nm}$ using a UV-VIS spectrophotometer (Shimadzu UV-24001 $\mathrm{PC})$.

\section{Results and discussion}

\section{Electrochemical reduction of $S A, A S A$}

Electrochemical reduction of salicylic (SA) and acetylsalicylic (ASA) acid was studied at a Pt electrode using the cyclic voltammetry $(\mathrm{CV})$ method.

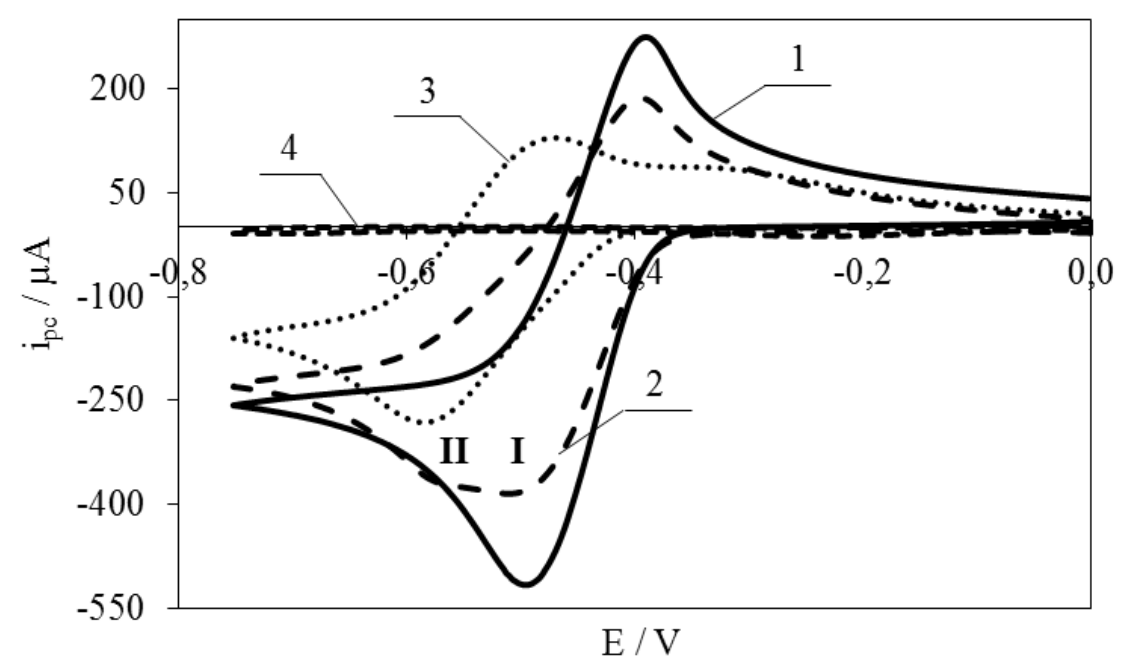

Figure 2. Cyclic voltammograms recorded at Pt electrode for electroreduction of SA (curve 1), ASA (curve 2), acetic acid (AA, curve 3) and in the supporting electrolyte (curve 4); $\mathrm{v}=0.01 \mathrm{~V} \mathrm{~s}^{-1} ; \mathrm{c}=5.0 \mathrm{mmol} \mathrm{L}{ }^{-1}$ in $0.1 \mathrm{~mol} \mathrm{~L}^{-1} \mathrm{NaClO}_{4}$.

Fig. 2 (curve 1) shows the voltammogram of SA electroreduction proving that the test compound is reduced in at least one step $\left(E_{p}=-0.49 \mathrm{~V}\right)$ at potentials lower than the potential at which hydrogen evolution starts. In the reverse scan, a peak observed at $-0.39 \mathrm{~V}$ is ascribed to oxidation of SA reduced form. Whereas, 
the voltammogram of ASA electroreduction presented in Fig. 2 (curve 2) proves that this process proceeds in at least two steps at potentials lower than the potential at which hydrogen evolution starts. Peak potential $\left(\mathrm{E}_{\mathrm{pc}}\right)$ of the first and second step in the electroreduction is $-0.50 \mathrm{~V}$ and $-0.57 \mathrm{~V}$, respectively. In the reverse scan, a peak observed at $-0.41 \mathrm{~V}$ is ascribed to oxidation of ASA reduced form. ASA electroreduction is preceded by its hydrolysis resulting in the formation of salicylic (SA) and acetic (AA) acid. The potential of the first peak of ASA electroreduction (Fig. 2, curve 2) corresponds to the potential of SA electroreduction peak (Fig. 2, curve 1). On the other hand, the potential of the second peak of ASA electroreduction (Fig. 2, curve 2) corresponds to the potential of AA electroreduction (Fig. 2, curve 3). Probably, the electroreduction of SA is followed by AA electroreduction. The electroreduction of SA, ASA and $\mathrm{AA}$ is quasi-reversible. Within the potential range, where reduction peaks of the tested compounds appear, the supporting electrolyte $\left(0.1 \mathrm{~mol} \mathrm{~L}^{-1} \mathrm{NaClO}_{4}\right)$ shows no peaks (Fig. 2, curve 4) [22].

The voltammograms were also used in determination of half-wave potentials $\left(\mathrm{E}_{1 / 2}\right)$ of $\mathrm{SA}, \mathrm{ASA}$ and AA reduction. This parameter provides information on the electroreductive properties of the compounds. The lower value of $\mathrm{E}_{1 / 2}$ proves that the tested compound is less susceptible to reduction. $\mathrm{SA}\left(\mathrm{E}_{1 / 2}=-0.455 \mathrm{~V}\right)$ is reduced easier than $\mathrm{ASA}\left(\mathrm{E}_{1 / 2}=-0.465 \mathrm{~V}\right)$, while AA $\left(\mathrm{E}_{1 / 2}=-0.706 \mathrm{~V}\right)$ is reduced the most difficult.

\section{Determination of the tested substances in pharmaceutical products}

Determination of active substances concentrations in the selected pharmaceuticals was carried out using the cyclic voltammetry method (Fig. 3). The tested pharmaceuticals were as follows: salicylic alcohol, Bayer aspirin, etopirin and polopirin.

Active substances contained in the pharmaceuticals are reduced quasi-reversibly in a potential range lower than the potential at which hydrogen evolution starts. Half-wave potentials $\left(\mathrm{E}_{1 / 2}\right)$ determined from the voltammograms for different pharmaceuticals are as follows: salicylic alcohol $(-0.469 \mathrm{~V})$, Bayer aspirin ($0.490 \mathrm{~V})$, etopirin $(-0.469 \mathrm{~V})$ and polopirin $(-0.467 \mathrm{~V})$. This indicates that polopirin is reduced the easiest and Bayer aspirin is reduced the most difficult.

Based on the cathodic peak current $\left(i_{p c}\right)$ and dependence of $i_{p c}$ on ASA and SA concentrations (Fig. 4) determined with cyclic voltammetry, we have calculated the concentration of the tested substrates in pharmaceutical products. The concentrations of the active substances in the pharmaceuticals determined electrochemically and the contents provided by the manufacturers are presented in Table 1. 


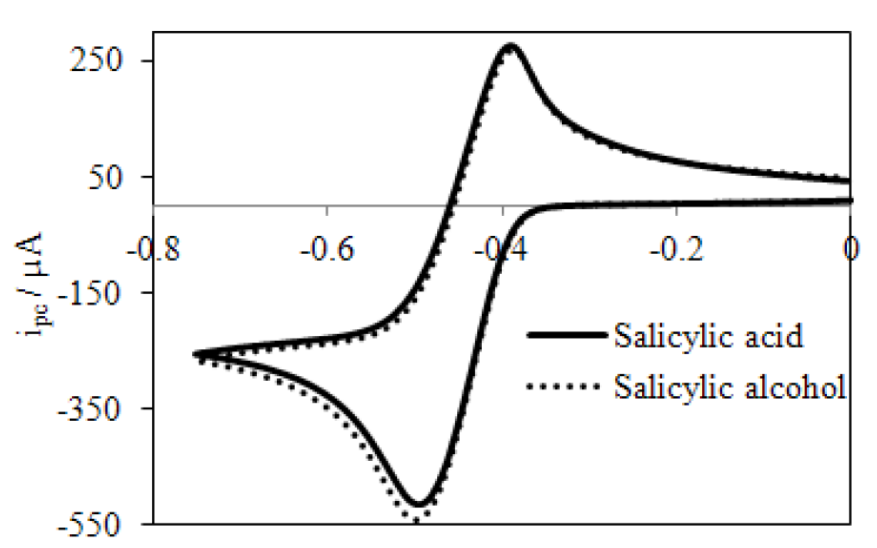

(A)

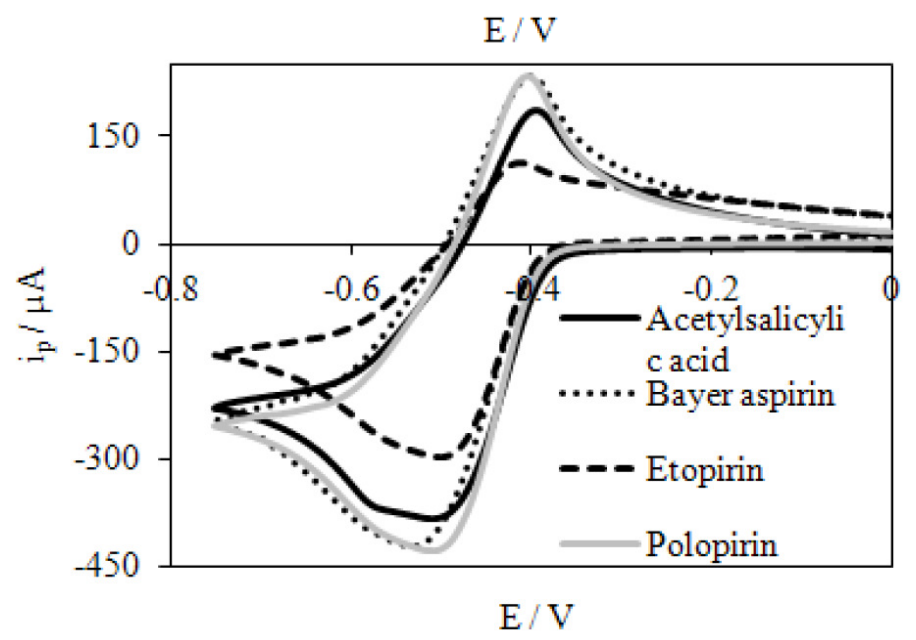

(B)

Figure 3. Cyclic voltammograms of electroreduction pharmaceutical products containing the active substances: salicylic acid (A) and acetylsalicylic acid (B); in 0.1 $\mathrm{mol} \mathrm{L}^{-1} \mathrm{NaClO}_{4}, \mathrm{v}=0.01 \mathrm{~V} \mathrm{~s}^{-1}$.

Table 1. Contents of the active substances in the selected pharmaceutical products.

\begin{tabular}{ccccc}
\hline $\begin{array}{c}\text { Active } \\
\text { substance }\end{array}$ & $\begin{array}{c}\text { Pharmaceutical } \\
\text { product }\end{array}$ & $\begin{array}{c}\text { Active substance } \\
\text { in the content } \\
\text { pharmaceutical } \\
\text { product*, }\end{array}$ & $\begin{array}{c}\text { Congentration of } \\
\text { active substance in } \\
\text { the pharmaceutical } \\
\text { product*, (mM) }\end{array}$ & $\begin{array}{c}\text { Determined } \\
\text { concentration of the } \\
\text { active substance in } \\
\text { a pharmaceutical } \\
\text { product, }(\mathbf{m M})\end{array}$ \\
\hline $\begin{array}{c}\text { Salicylic acid } \\
\text { (SA) }\end{array}$ & Salicylic alcohol & $20^{* *}$ & $7.24 * *$ & $5.32 \pm 0.1$ \\
\hline & Bayer aspirin & 500 & 5.55 & $5.20 \pm 0.1$ \\
\cline { 2 - 5 } & Etopirin & 300 & 3.33 & $3.67 \pm 0.1$ \\
\cline { 2 - 5 } $\begin{array}{c}\text { Acetylsalicylic } \\
\text { acid (ASA) }\end{array}$ & Polopirin & 500 & 5.55 & $5.34 \pm 0.1$
\end{tabular}

*according to the manufacturer (in 1 pill)

**according to the manufacturer (in $1 \mathrm{~g}$ )

The concentrations determined by the electrochemical method are slightly different from those calculated on the base of the contents provided by manufacturers. Differences in the concentrations can be attributed to the presence of excipients in this pharmaceutical. Due to the fact that the dependences of the peak currents on the concentration of all tested compounds are linear, the cyclic 
voltammetry can be successfully applied in the determination of active substances concentrations in commonly used pharmaceuticals.

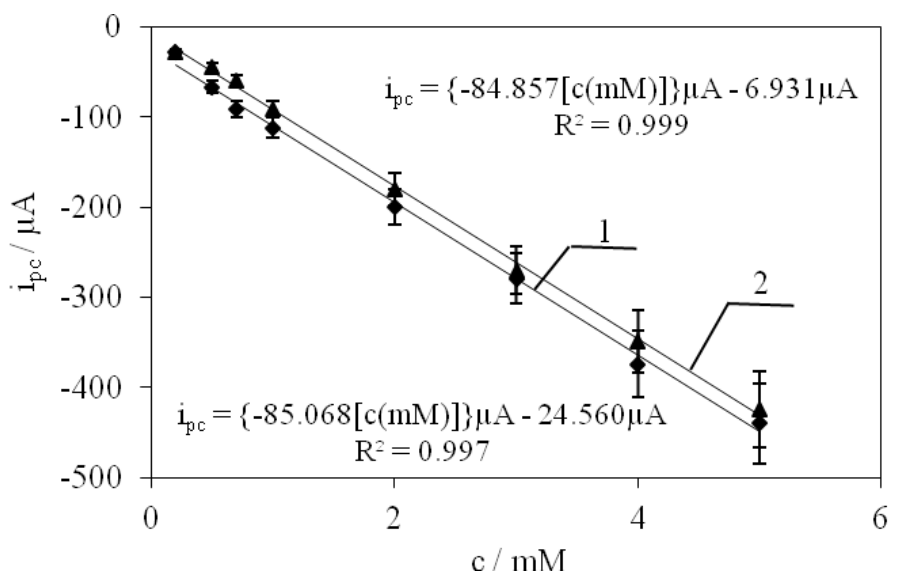

Figure 4. Dependence of the cathodic peak current on SA (curve 1) and ASA (curve 2) concentrations in their electroreduction at the Pt electrode; $\mathrm{v}=0.01 \mathrm{~V} \mathrm{~s}^{-1}$.

\section{UV-Vis spectrophotometry of the active substances and pharmaceutical products}

Salicylic (SA) and acetylsalicylic (ASA) acids were determined in the pharmaceutical products using a spectrophotometric method (Fig. 5). Spectrophotometric spectra were recorded in the wavelength range from 180 to $800 \mathrm{~nm}$. UV-VIS spectra recorded separately in solutions of active substances and pharmaceuticals showed three absorption bands [24].
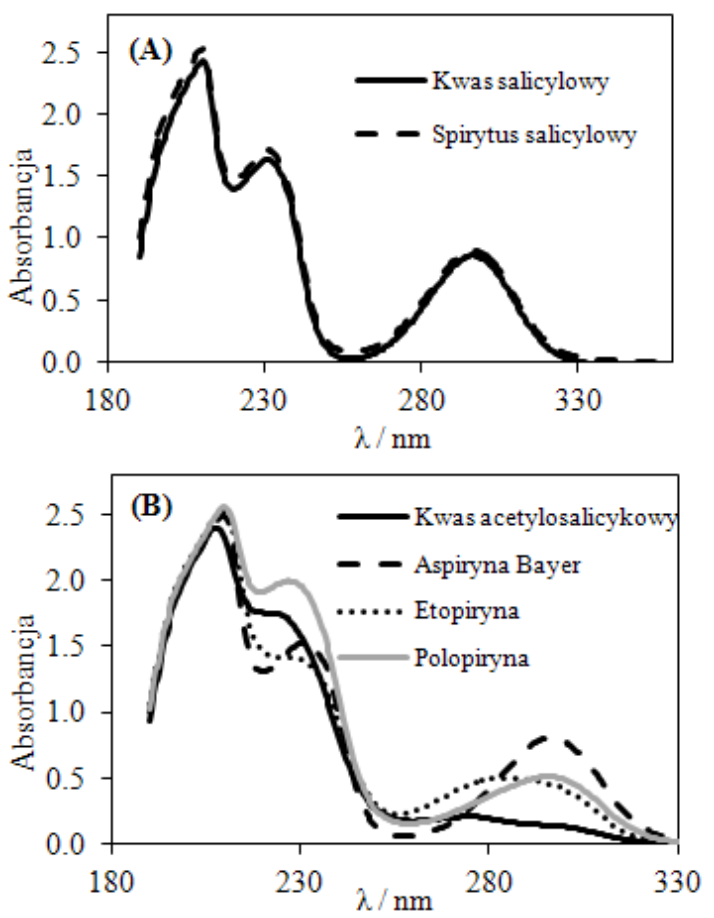

Figure 5. UV-VIS spectra recorded in solutions of pharmaceutical products containing the active substances: salicylic (A) and acetylsalicylic (B) acid. 
Fig. 5A presents spectra recorded in SA and salicylic alcohol. These spectra include three bands. The first band at 212 and the third one at $300 \mathrm{~nm}$ can be attributed to interactions of carboxylic substituents with aromatic rings. The second band at $235 \mathrm{~nm}$ can be related to interactions of hydroxyl groups also with aromatic rings. Spectra recorded in these two solutions overlap, what means that the concentration of the active substance was the same. Similar bands were observed at UV-VIS spectra recorded in ASA and tested pharmaceuticals solutions (Fig. 5B). Concentrations of active substances determined from UVVIS spectra correlate with the concentrations determined from voltammetric curves.

\section{Conclusions}

The electroreduction behaviour of SA and ASA was investigated at Pt electrode. SA and ASA is reduced quasi-reversibly at Pt electrode at the potentials higher than the potential at which hydrogen evolution starts. SA $\left(\mathrm{E}_{1 / 2}=-0.455 \mathrm{~V}\right)$ is reduced easier than $\operatorname{ASA}\left(\mathrm{E}_{1 / 2}=-0.465 \mathrm{~V}\right)$, while AA $\left(\mathrm{E}_{1 / 2}=-0.706 \mathrm{~V}\right)$ is reduced the most difficult. Concentrations of the active substances in the tested pharmaceuticals determined using electroanalytic and spectrophotometric methods are slightly different from the concentrations provided by the manufacturers. Differences can be related to the presence of excipients in pharmaceuticals. The voltammetric method can be applied in-determining active substance contents in pharmaceuticals products.

\section{References}

1. de la Pena AM, Salinas F, Meras ID. Anal Chem. 1988;60:2493-2496.

2. Samborska R. Anest Ratow. 2009;3:132-135.

3. Pastuszka M, Kaszuba A. Post Derm Alergol. 2012;3:205-214.

4. Międzybrodzki R. Post Hig Med Dosw. 2004;58:438-448.

5. Vane JR, Botting RM. Thromb Res. 2003;110:255-258.

6. Awtry EH, Loscalzo J. Circulation. 2000;101:1206-1218.

7. Wang Z, Li H, Chen J, et al. Talanta. 2011;85:1672-1679.

8. Reguła J, Wocial T, Kraszewska E, et al. Gastroenterol Klin. 2011;3:72-78.

9. Muralidharanb B, Gopu G, Vedhi C, et al. Appl Clay Sci. 2008;42:206-213.

10. Yardim Y, Leventa A, Keskin E, et al. Talanta. 2011;85:441-448.

11. Wudarska E, Chrzescijanska E, Kusmierek E, et al. Electrochim Acta. 2013;93:189-194.

12. Atta NF, Galal A, Azab SM. Int J Electrochem Sci. 2011;6:5082-5096.

13. Babaei A, Taheri AR, Afrasiab M. J Brazil Chem Soc. 2011;22:1549-1558.

14. Masek A, Chrzescijanska E, Zaborski M. Int J Electrochem Sci. 2014;9:7904-7915.

15. Alghamdi AF. Port Electrochim Acta. 2014;32:51-64.

16. Du L, Liu X, Huang W, et al. Electrochim Acta. 2006;51:5754-5760.

17. Masek A, Chrzescijanska E, Zaborski M. Food Chem. 2014;148:18-23.

18. Brett AMO, Ghica ME. Electroanalysis. 2003;159:1745-1750. 
19. Kissinger PT, Heinema WH. Laboratory techniques in electroanalytical chemistry. 2nd Ed. New York: Marcel Dekker; 1996.

20. Bard AJ, Faulkner LR. Electrochemical methods, fundamentals and applications. 2nd Ed. New York: John Wiley and Sons; 2001.

21. Brett CMA, Brett AMO. Electrochemistry: principles, methods and applications. New York: Oxford University Press; 1993.

22. Chrzescijanska E, Wudarska E, Kusmierek E, et al. J Electroanal Chem. 2014;713:17-21.

23. Rao CN, Subbarayudu $\mathrm{K}$, Rao $\mathrm{CN}$, et al. Port Electrochim Acta. 2010;28:349-357.

24. Santos AL, Takeuchi RM, Stradiotto NR. Curr Pharm Anal. 2009;5:69-88. 